\title{
Emiliania huxleyi: bloom observations and the conditions that induce them
}

\author{
Toby TYRRELL and Agostino MERICO \\ School of Ocean and Earth Science, Southampton Oceanography Centre, Southampton \\ University, European Way, Southampton, SO14 3ZH. tt@ soc.soton.ac.uk, \\ a.merico@soc.soton.ac.uk.
}

\section{Summary}

Most of what is known about the distribution of blooms of Emiliania huxleyi comes from satellite evidence. However, patches of bright water in satellite images are not always E. huxleyi blooms and satellite evidence needs to be verified by in situ sampling in the area. In this article we firstly describe the observational evidence for these blooms in various regions of the global ocean, and then proceed to describe mimicking conditions: the occasional bright waters that are not $E$. huxleyi blooms. In the second part of this article we discuss the possible causes of the E. huxleyi blooms. We review the various hypotheses concerning the water conditions required to generate these blooms.

\section{Introduction: distribution and environmental effects}

Emiliania huxleyi (Fig. 1) is an extremely cosmopolitan coccolithophore species. In addition to the spectacular blooms that are enumerated below, it occurs in lesser (but still significant) numbers in all oceans except the Arctic Ocean and highlatitude Southern Ocean (Winter et al. 1994), with either complete absence or just a few (remnant?) cells observed in the latter two areas (e.g. Winter et al. 1999; Findlay and Giraudeau, 2000). While E. huxleyi blooms occur in relatively eutrophic regions (e.g. following diatom spring blooms in temperate latitudes), the species is also rather numerous in the permanently oligotrophic waters of the subtropical gyres. It is frequently the most numerous species in phytoplankton cell counts from surface water samples, although because of the rather small size of the cells (circa $5 \mu \mathrm{m}$ in diameter), it makes a lesser contribution to total biomass. In fact, for the same reason, E. huxleyi blooms are usually associated with low rather than high chlorophyll- $a$ concentrations. 'Bloom', as generally used, is a 


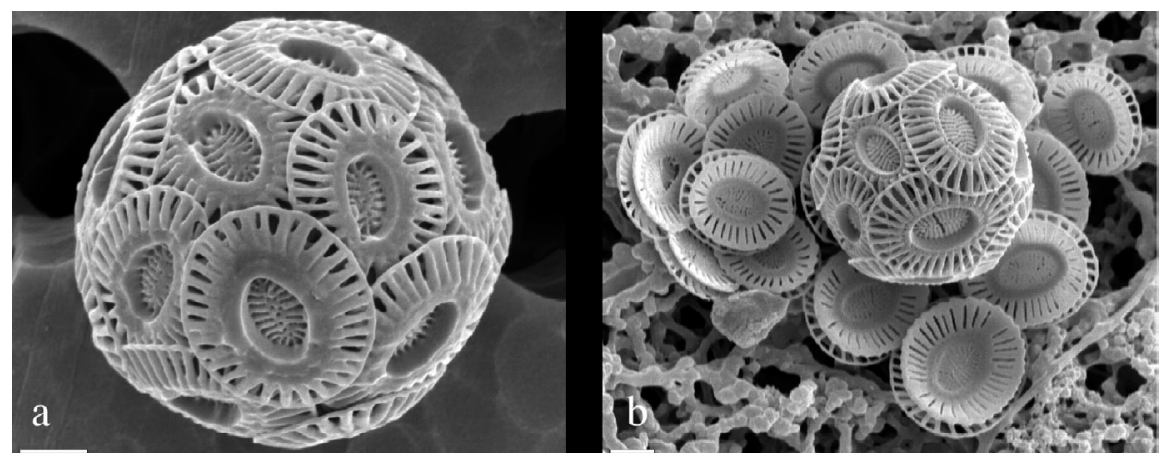

Fig. 1. Emiliania huxleyi cell a. surrounded by attached coccoliths, and b. with coccoliths shedding off (images courtesy of Markus Geisen and Jeremy Young).

rather imprecise term, but in this paper it is defined, arbitrarily, to refer only to $E$. huxleyi cell concentrations of at least 1,000,000 per liter. Blooms can cover very large areas, for instance at least $200,000 \mathrm{~km}^{2}$ in the Eastern Bering Sea and Bering Straits in 1997 (Sukhanova and Flint 1998), and 250,000 km² in the North Atlantic south of Iceland in 1991 (Holligan et al. 1993a). Cell concentrations vary between blooms and according to the stage of the bloom (sometimes bright waters contain

Table 1. Field evidence verifying that many areas of bright waters in satellite images correspond to areas where very high Emiliania huxleyi cell numbers are observed.

\begin{tabular}{lccl}
\hline Bloom Location & $\begin{array}{c}\text { Concentration } \\
\left(10^{6} \text { cells litre }\right.\end{array}$ & Year & Source \\
\hline Norwegian fjords & $10-100$ & $1950 \mathrm{~s}$ & Birkenes and Braarud 1952 \\
& up to 115 & 1955 & Berge 1962 \\
& up to 7 & 1992 & Kristiansen et al. 1994 \\
North Sea & $<0.1->1$ & '80s & Holligan et al. 1993b \\
& $0.1-1.2$ & 1993 & Van der Wal et al. 1995 \\
& $1-6$ & 1994 & Head et al. 1998 \\
Western English & $0.6-2.3$ & 1999 & Burkill et al. 2002 \\
Channel & up to 8.5 & '80s & Holligan et al. 1983 \\
Bay of Biscay & up to 2 & 1992 & Garcia Soto et al. 1995 \\
North Atlantic & up to 3 & 1998 & Lampert et al. 2002 \\
& up to 4 & 1987 & Malin et al. 1993 \\
Gulf of Maine & $0-10$ & 1991 & Holligan et al. 1993a \\
& $<0.5->2$ & $1988-89$ & Balch et al. 1991 \\
Nova Scotian shelf & $>1$ & $1988-90$ & Townsend et al. 1994 \\
Black Sea & Up to 1.5 & 1991 & Brown and Yoder 1993 \\
& Up to 10 & 1992 & Mankovsky et al. 1996 (cited in \\
Bering Sea & & & Cokacar et al. 2001) \\
\hline
\end{tabular}


abundant light-scattering coccoliths left over from a cell population that has mostly died). E. huxleyi is unusual amongst coccolithophores in that under certain environmental conditions the cells overproduce coccoliths (Paasche 2002), leading to shedding of excess coccoliths and very large concentrations of detached coccoliths in the water. Light scattering is by both detached coccoliths and coccoliths within coccospheres. Some example measured cell concentrations are given in Table 1. The highest concentration ever reported is $115,000,000$ cells per liter, from a Norwegian fjord in 1955 (Berge 1962) (Table 1).

The blooms have significant regional environmental impacts (Westbroek et al. 1993), via increased water albedo (reflectance) (Tyrrell et al. 1999), DMS production (Malin and Steinke this volume), large fluxes of calcium carbonate out of the surface waters and changes in the oceanic uptake of $\mathrm{CO}_{2}$ (Rost and Riebesell this volume). Because of the light scattering properties of the coccoliths, bloom water is very turbid. This leads to increased light/heat trapping in the surface layers, decreased light/heat penetration to depth, and increased reflection of light/heat back out of the sea surface (Tyrrell et al. 1999). The impacts of the blooms on oceanatmosphere exchange of $\mathrm{CO}_{2}$ has been investigated on several occasions (Robertson et al. 1994; Van der Wal et al. 1995; Murata and Takizawa 2002).

\section{History of bloom observations}

To the best of our knowledge, the first reported observations of E. huxleyi blooms and associated milky-turquoise waters came from fjords on the western coast of Norway (Birkenes and Braarud 1952; Berge 1962). Blooms continue to occur in Norwegian waters at the present time, including offshore out to many miles, as shown for instance in a satellite image from May 2000 in which an enormous bloom stretches up from the Skaggerak and a long way up the western Norwegian coastline http://www.soes.soton.ac.uk/staff/tt/eh/pics/sat/skag2.jpg.

As satellites started being used to look at the sea, E. huxleyi blooms started being picked up in these images. The possibility that large areas of the open ocean could be significantly paler in color was simply not appreciated to any great extent (although see Hardy 1956) before these satellite images were available. Some of the first satellite studies concentrated on areas to the west of the English Channel (Holligan et al. 1983), or off the west coast of France http://www.soes.soton. ac.uk/staff/tt/eh/v_0.htm. High-resolution modern SeaWiFS (Table 2) images show that small E. huxleyi blooms occur all along the NW European shelf break from the Bay of Biscay up to the west coast of Ireland http://www.soes.soton. ac.uk/staff/tt/eh/pics/sat/three.tif. Whereas probably the first $E$. huxleyi bloom ever to be seen in a satellite image was in a LANDSAT-1 (Table 2) image http://www.soes.soton.ac.uk/staff/tt/eh/v_1.htm, later studies made use of AVHRR (Table 2) images, for on the Nova Scotian shelf and Grand Bank (Brown and Yoder 1993), in the Gulf of Maine (Balch et al. 1991) and in the North Sea (Holligan et al. 1993b). Much of the first biological and optical information was obtained in the Gulf of Maine (Balch et al. 1991). In 1991 an enormous bloom was seen in 
AVHRR images south of Iceland, covering 250,000 km² (Holligan et al. 1993a), and ships traveled from the UK to sample it (Holligan et al. 1993a) and to measure its impact on carbon dioxide concentrations (Robertson et al. 1994). Blooms are still seen south of Iceland in SeaWiFS images http://www.soes.soton.ac.uk/staff/ tt/eh/pics/sat/natl1.jpg

Other early satellite work with E. huxleyi blooms involved the development of an automatic technique to scan CZCS images for the presence of coccolithophore blooms (Brown and Yoder 1994). CZCS images were rather low resolution (each individual pixel corresponded to a rather large area of the Earth's surface) but CZCS's global coverage allowed construction of a global map of where E. huxleyi blooms (or at least white waters, most of which are E. huxleyi blooms) occur (Brown and Yoder 1994). The global map from the CZCS years (1978-86) gave us our first wide-ranging insight into the distribution of blooms of any single phytoplankton species. As expected from previous work, the North Sea and northern North Atlantic areas showed up as areas of particularly high E. huxleyi activity. The North Pacific was shown to be generally less favorable for E. huxleyi blooms than the North Atlantic. Less expected was the discovery that E. huxleyi

Table 2. Satellites used for Emiliania huxleyi bloom observations.

\begin{tabular}{|c|c|c|c|c|}
\hline Acronym & Full name & $\begin{array}{l}\text { Dates of op- } \\
\text { eration }\end{array}$ & $\begin{array}{l}\text { Number of } \\
\text { visible } \\
\text { wavebands }\end{array}$ & $\begin{array}{l}\text { Spatial resolution } \\
(\mathrm{km})\end{array}$ \\
\hline LANDSAT* & $\begin{array}{l}\text { LAND remote- } \\
\text { sensing SATellite }\end{array}$ & $\begin{array}{l}1972-\text { still } \\
\text { operating }\end{array}$ & 3 & 0.03 \\
\hline CZCS & $\begin{array}{l}\text { Coastal Zone Color } \\
\text { Scanner }\end{array}$ & $1978-1986$ & 4 & $18^{\dagger}$ \\
\hline AVHRR & $\begin{array}{l}\text { Advanced Very } \\
\text { High Resolution } \\
\text { Radiometer }\end{array}$ & $\begin{array}{l}1978-\text { still } \\
\text { operating }\end{array}$ & 1 & $4^{\dagger}$ \\
\hline OCTS & $\begin{array}{l}\text { Ocean Color and } \\
\text { Temperature Scan- } \\
\text { ner }\end{array}$ & $\begin{array}{l}08 / 1996- \\
07 / 1997\end{array}$ & 6 & 0.7 \\
\hline SeaWiFS & $\begin{array}{l}\text { Sea viewing Wide } \\
\text { Field of view Sen- } \\
\text { sor }\end{array}$ & $\begin{array}{l}1997-\text { still } \\
\text { operating }\end{array}$ & 6 & 4.5 or $9^{\dagger}$ \\
\hline MODIS & $\begin{array}{l}\text { MODerate resolu- } \\
\text { tion Imaging Spec- } \\
\text { troradiometer }\end{array}$ & $\begin{array}{l}1999-\text { still } \\
\text { operating }\end{array}$ & 10 & 1 or $5^{\dagger}$ \\
\hline MERIS & $\begin{array}{l}\text { MEdium Resolution } \\
\text { Imaging Spec- } \\
\text { trometer instrument }\end{array}$ & $\begin{array}{l}2002-\text { still } \\
\text { operating }\end{array}$ & 8 & 1 or $5^{\dagger}$ \\
\hline
\end{tabular}


blooms apparently blanket the Patagonian shelf (between Argentina and the Falkland Islands) on a regular basis, as also seen in recent SeaWiFS images during November and December of different years http://www.soes.soton.ac.uk/staff/ $\mathrm{tt} / \mathrm{eh} /$ pat.html. Elsewhere in the southern hemisphere E. huxleyi blooms were detected less frequently than in the northern hemisphere (Brown and Yoder 1994). Brown and Yoder recognized from the start the possibility of certain water conditions masquerade as E. huxleyi blooms (see below for more discussion), and therefore that their global map was not foolproof.

Since 1997 the "tool of choice" for sensing E. huxleyi blooms has been the SeaWiFS sensor (Table 2), although new sensors such as MODIS and MERIS (Table 2) are proving equally capable of detecting the blooms. As well as confirming blooms in locations where CZCS saw them, SeaWiFS has also returned images of what appear to be extensive E. huxleyi blooms where CZCS saw none. In the Barents Sea, for example, where CZCS detected no blooms (although this area is near the sensor's latitudinal limit) SeaWiFS has seen many extensive areas of pale waters (July-September 1997-2002) that are most likely E. huxleyi blooms. There was apparently little $E$. huxleyi activity in the Black Sea during 1978-86, according to CZCS (Brown and Yoder 1994), but there have since been many basin-wide blooms (Cokacar et al. 2001). SeaWiFS has also seen many areas of moderately pale waters north of the Antarctic Polar Front in the Southern Ocean, for instance between Tasmania and New Zealand http://www.soes.soton. ac.uk/staff/tt/eh/pics/sat/tasnz.jpg. The biggest surprise of the last few years, however, has been the dramatic appearance of E. huxleyi in the eastern Bering Sea http:// www.soes.soton.ac.uk/staff/tt/eh/ebs.html. In some of the very first images that SeaWiFS sent back to Earth in September 1997, virtually the whole of the eastern Bering Sea (over the continental shelf) was blanketed by a dense E. huxleyi bloom that persisted for many months, approximately from July to October. Local fishermen asserted that the phenomenon was completely new, which has been largely substantiated by a detailed analysis of earlier satellite images of the region (Merico et al. 2003). Careful inspection of CZCS images in 1978-86 and AVHRR images in 1987-1996 revealed no evidence of earlier E. huxleyi blooms. Nonetheless, a small patch of bright water (almost certainly, from its location and persistence, a patch of E. huxleyi) was visible to the south of St. Matthew Island from the $26^{\text {th }}$ of August to the $3^{\text {rd }}$ of October 1996 (Merico et al. 2003). This small bloom was probably a precursor to the much larger blooms starting the following year.

Intense and widespread E. huxleyi blooms also occurred in the eastern Bering Sea in 1998, 1999 and 2000, although not in 2001 or 2002. It is not clear as yet what impact these blooms have on the higher trophic levels of the Bering Sea ecosystem. However, some effects have been observed and considered as direct consequences of these events. In particular, a massive die-off of short-tailed shearwaters took place in summer 1997 (Baudini et al. 2001). The lower body mass and lipid values of the birds suggested starvation as the most likely cause of death. The fact that most of the carcasses were found within the extent of the coccolithophores bloom (Baudini et al. 2001) therefore indicated that the chalky 
(very turbid) waters might have played a role in reducing the ability of the birds to spot their prey from above the sea-surface.

A comprehensive and up-to-date coverage of where E. huxleyi blooms are occurring at the moment, and have occurred since 1997, can be obtained at Chris Brown's website http://orbit-net.nesdis.noaa.gov/orad2/doc/ehux_www.html.

\section{All that glitters is not E. huxleyi}

Not all bright waters are caused by E. huxleyi blooms. Alternative causes of bright waters are discussed in this section. What has been perhaps even more surprising about SeaWiFS images of the eastern Bering Sea is that blooms appear to have been taking place in the middle of winter (Iida et al. 2002). Given the high latitude, approximately between $56^{\circ} \mathrm{N}$ and $60^{\circ} \mathrm{N}$, wintertime blooms of any phytoplankton should be impossible. According to a well-substantiated theoretical understanding of phytoplankton dynamics in temperate locations experiencing spring blooms, of which the eastern Bering Sea is one, deep mixing and low surface sunlight levels should make net growth of phytoplankton (photosynthesis exceeding respiration) impossible in wintertime (e.g. Sverdrup 1953). But SeaWiFS and OCTS images show bright water patches resembling E. huxleyi blooms during for instance February, March, April and May from 1998 to 2000 (Iida et al. 2002; Fig. 1, Broerse et al. 2003), in all cases at times before the spring blooms took place in those years. Because of surprise at these apparent $E$. huxleyi blooms in winter, sampling was undertaken in February 2001 in order to be able to observe what was in the water and imparting the pale turquoise color (Broerse et al. 2003). The results were surprising.

Instead of seeing multitudes of coccoliths, we found instead that, at the brightest station on the transect, coccoliths were strongly outnumbered by empty (no living cells inside) diatom frustules (Fig. 2). From several lines of evidence it was determined that the diatom frustules were remnants from earlier blooms in the year, that had settled to seafloor but had then been resuspended by strong winds during stormy weather. The seafloor is not very deep over the continental shelf (average about 70 meters). Many of the frustules were broken up so that we were seeing more fragments than whole frustules. On the basis of measurements of the scattering properties of opal material, it was calculated that the observed concentration of diatom frustules and fragments was sufficient to produce the sea-surface brightness seen in the satellite images (Broerse et al. 2003).

These observations suggest that resuspension of broken-up diatom tests may also, perhaps, be responsible for other anomalous bright water patches, for in stance in winter over the Grand Banks on 03 Mar 2001 http://visibleearth.nasa. gov/cgi-bin/viewrecord?7769 and 28 Jan 2002 http://visibleearth.nasa.gov/cgi-bin/ viewrecord?11785. Other coccolithophore species can also turn the waters pale if blooming in sufficient numbers. For instance, the best documented example is of a bloom of Gephyrocapsa oceanica (Blackburn and Cresswell 1993) in the 


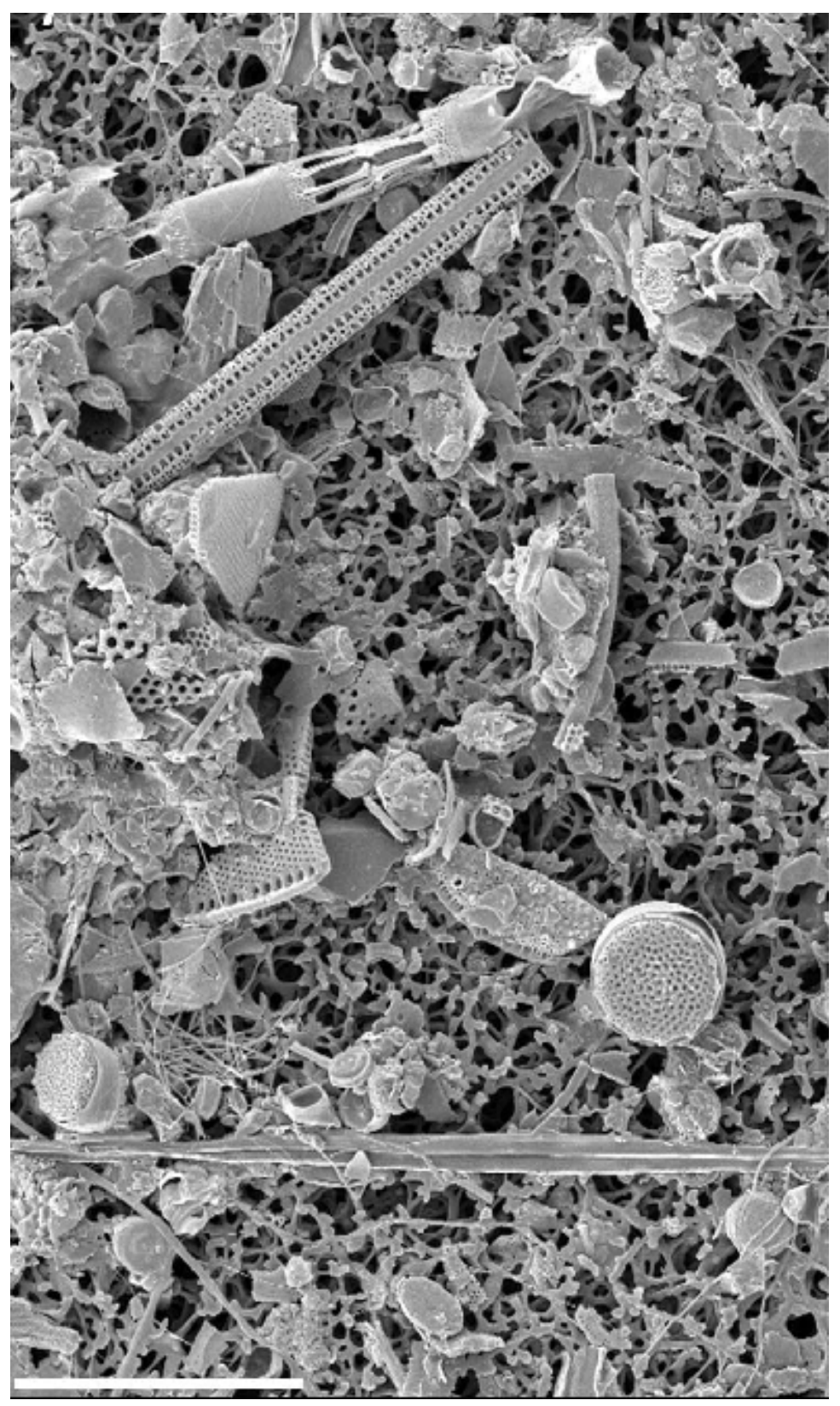

Fig. 2. Scanning electron microscope image from a wintertime bright water station in the eastern Bering Sea (Broerse et al. 2003). The suspended matter is dominated by broken up diatom frustules. 
coastal embayment of Jervis Bay on the east coast of Australia in mid December 1992, of which a striking photograph was taken (Blackburn and Cresswell 1993). In general, however, E. huxleyi is thought to be unique in overproducing coccoliths and then shedding the excess ones into the water (Paasche 2002), so it is likely that hardly any of the open-ocean bright waters are attributable to species other than E. huxleyi.

Other water conditions known to be able to mimic E. huxleyi blooms in appearance are: (1) shallow carbonate shelves such as in the Gulf of Carpentaria (Brown and Yoder 1994), and the Grand Banks of the Bahamas, (2) suspended sulphur granules (Weeks et al. 2002), and (3) glacial rock flour in some high-altitude lakes. Suspended sediment, for instance at river mouths, does not as a rule look the same as E. huxleyi blooms, because there is in this case usually a brownish tinge to the water color. Live diatom blooms (when the cells still occupy the frustules, as opposed to the wintertime Bering Sea case above) are usually much darker and browner (due to pigments in the diatoms) than are E. huxleyi blooms.

Because of the possibility of mimicking conditions, it is important to obtain in situ verification of the cause of each location of bright waters at each time of year. So, for instance, the summer/autumn bright waters have been positively identified (see Table 1 for more information) as E. huxleyi blooms in the Norwegian fjords (e.g. Berge 1962), in the North Sea (Holligan et al. 1993b; Van der Wal et al. 1995), in the North Atlantic (Holligan et al. 1993a), in the Bering Sea (Sukhanova and Flint 1998), and in the Gulf of Maine (Balch et al. 1991), and in the Black Sea (Mihnea 1997; Mankovsky et al. 1996).

Major areas of white water that appear to be E. huxleyi blooms but for which in situ confirmation is still urgently needed are: (1) the Barents Sea, (2) the Patagonian Shelf.

\section{What causes Emiliania huxleyi blooms?}

The second part of this article will concern the question as to which water conditions are conducive to the development of Emiliania huxleyi blooms. To put it another way, what is the ecological niche for E. huxleyi? We will now review several hypotheses for the environmental conditions that favor $E$. huxleyi blooms, the reasons for those hypotheses and the evidence in support of them. The ecology of all coccolithophores is also discussed in other chapters (Balch this volume; Rost and Riebesell this volume). The physiology of E. huxleyi is discussed in detail elsewhere (Paasche 2002; Brownlee and Taylor this volume) and is not covered here.

\section{High light}

The first hypothesis is that high light conditions trigger E. huxleyi blooms. Evidence for this hypothesis was put forward by Nanninga and Tyrrell (1996), and is partially recapitulated here, together with more recent evidence. A literature 
search of reports of natural blooms of E. huxleyi (and the associated measured water conditions) reveals that they all occur in highly stratified water where the mixed layer depth is usually $\sim 10-20 \mathrm{~m}$, and is always $\leq 30 \mathrm{~m}$ (Nanninga and Tyrrell 1996). As an example, the most intense bloom ever reported in the literature occurred in a fjord SE of Norway in May-July 1955 (Berge 1962). There were a staggering $115,000,000$ E. huxleyi cells per liter. There was very little monitoring of the environment prior to the bloom, but Berge noted:

" $\ldots$ in the summer of 1955 , the intensity and extent of the discoloration was so remarkable that quite unusual ecological conditions must have existed. ... The tentative conclusion is drawn that high light intensities during May and June 1955 acted selectively on the plankton, giving E. huxleyi advantageous conditions."

Some of the best data we have on conditions leading to E. huxleyi success in competition with other phytoplankton comes from mesocosms in Norwegian fjords, run by Jorun Egge and others at the University of Bergen. Fig. 3 shows the sizes of E. huxleyi and Phaeocystis populations in mesocosm bags having experienced different nutrient and light conditions. The initial water in the bags was fjord water with an unaltered natural assemblage of phytoplankton. Although many phytoplankton species were present, only the final populations of E. huxleyi and Phaeocystis are shown for clarity. We can see that the large black circles $(E$. huxleyi blooms) in Fig. 3 occur mostly to the top of each plot, i.e. following higher-than-average light intensities.

The large E. huxleyi bloom south of Iceland in 1991 was modeled and high light was shown to be a possible cause (Tyrrell and Taylor 1996). Fig. 4 shows the temperature structure of the water along a north-south transect through the bloom. To the north of the transect where the bloom was most intense, so too is the stratification. Mixing is not very deep and so average light intensities in the surface layer are high.

The most notable difference to the environment of the eastern Bering Sea in 1997, the year of the first massive E. huxleyi blooms, was unusually strong stratification from June onwards, following a single strong storm in May (Stabeno et al. 2001). The bloom was first noted in early July, by scientists out at sea (Sukhanova and Flint 1998). A mooring station collected time series of temperature and salinity profiles data continuously through the beginning of the bloom as well as in previous and in subsequent years (Stabeno et al. 2001; Hunt and Stabeno 2002). The very strong stratification in June/July 1997 is apparent (Fig. 5, Hunt and Stabeno 2002).

Further objective evidence for the importance of stratification to the genesis of E. huxleyi blooms comes from recent work on the Black Sea. A study of satellite images (Cokacar et al. 2001) found that E. huxleyi blooms did not occur randomly with respect to the circulation structure of the Black Sea, but rather that E. huxleyi bright waters were more frequently associated with cyclonic as opposed to anticyclonic eddies. The surface waters of cyclonic eddies tend to be more strongly stratified than those of anti-cyclonic eddies.

An innovative recent study has compared E. huxleyi bloom occurrence on a global scale (as detected in SeaWiFS images using an automatic algorithm: 

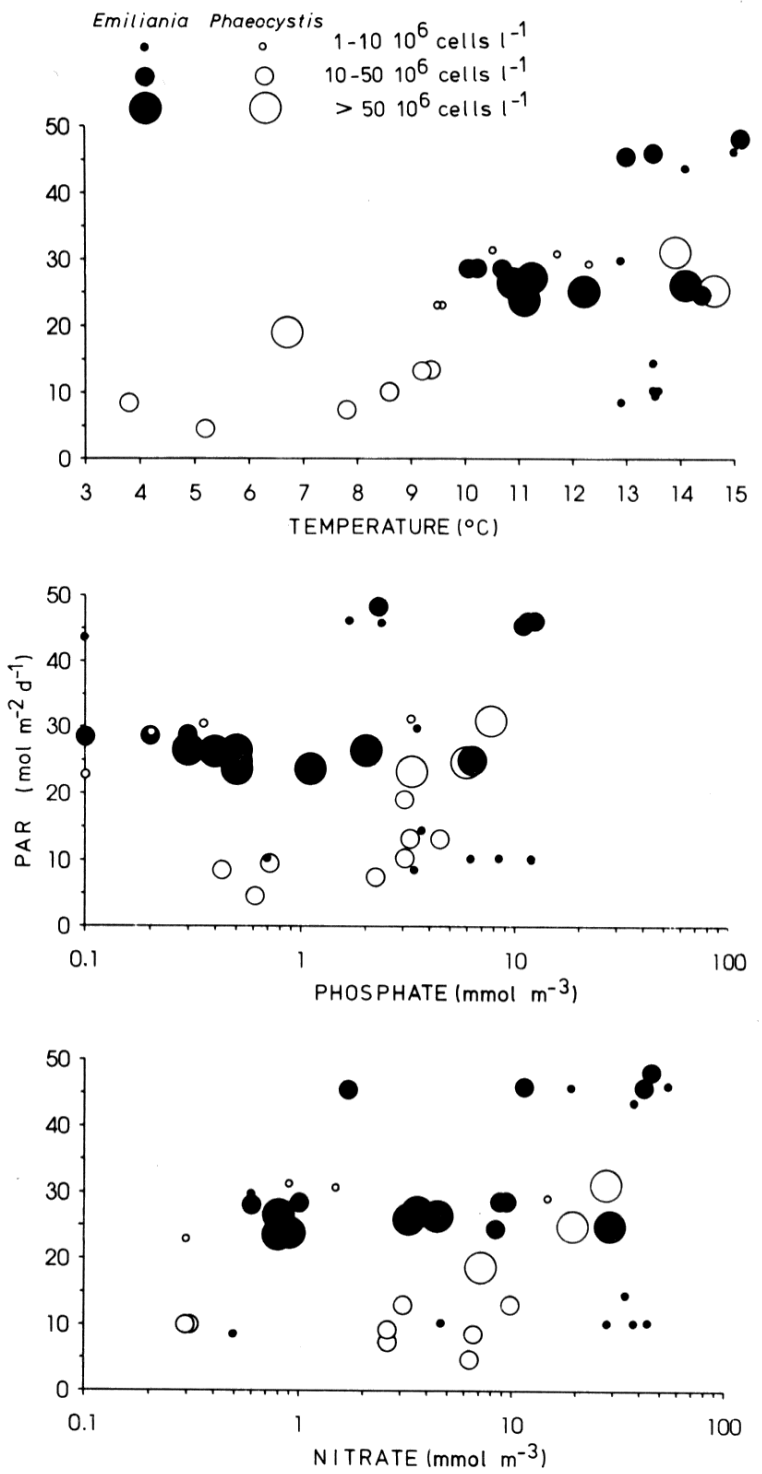

Fig. 3. Magnitudes of mesocosm blooms of Emiliania huxleyi and Phaeocystis versus several environmental variables (from Egge and Heimdal 1994). Light, nutrients and temperature are 5-day averages, over the five days prior to the measurement of phytoplankton concentration. 


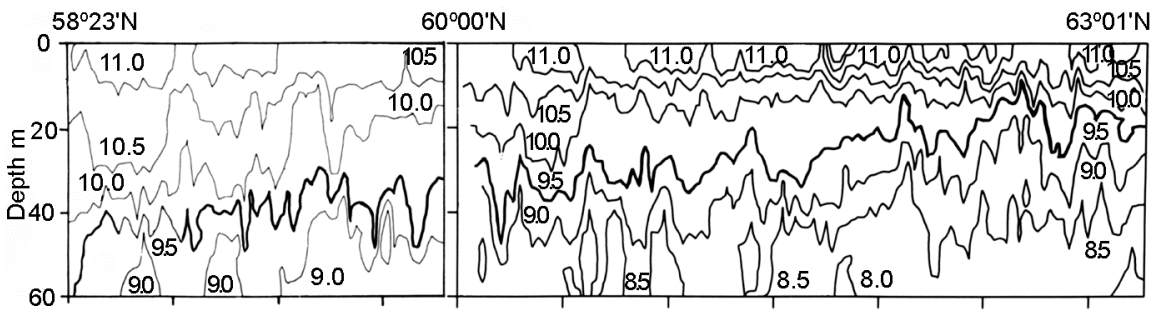

Fig. 4. Temperature along a north-south transect through an Emiliania huxleyi bloom south of Iceland, 1991 (taken from Holligan et al. 1993a). Highest E. huxleyi concentrations are towards the northern end of the transect.

http://orbit-net.nesdis.noaa.gov/orad2/doc/ehux_www.html, but with shallow lowlatitude sites excluded because similar reflectance is generated by resuspended calcareous sediments) with datasets of physical and nutrient parameters (IglesiasRodriguez et al. 2002). The study involved an objective analysis of parameters correlated with E. huxleyi blooms, although such correlations do not necessarily imply causation (for instance some association between E. huxleyi blooms and stratified waters is to be expected due to an effect of the blooms on the water state rather than vice-versa). Their results suggest that $E$. huxleyi blooms are "confined primarily to nutrient-depleted, temperate, and high-latitude oceans with relatively high critical irradiances." (Iglesias-Rodriguez et al. 2002).

Nanninga and Tyrrell (1996) suggested that the reason E. huxleyi outcompetes other phytoplankton at high light intensities is that $E$. huxleyi is uniquely tolerant of high light intensities. That is to say, E. huxleyi is not prone to photoinhibition, in contrast to other phytoplankton. Laboratory and field PI-curves in which $E$. huxleyi has been acclimatized to and tested at high light intensities show a lack of photo-inhibition, even at the highest light intensities likely to be encountered in nature (Balch et al. 1992; Nanninga and Tyrrell 1996). While unusual tolerance of high light intensities may turn out to be important (but see Stolte et al. 2000), the evidence is not conclusive and there is no accepted physiological reason (e.g. unique pigments) why E. huxleyi should outperform other phytoplankton at high light. It is known that coccoliths do not act as "sunscreens" (Paasche and Klaveness 1970).

\section{Low silicate}

E. huxleyi is a fast-growing ( $r$-selected) phytoplankton species, capable under favorable conditions of multiplying more rapidly than most other species. Most diatoms, however, can multiply even more rapidly (Furnas 1990). Diatoms are typically the fastest-growing of all phytoplankton and dominate in eutrophic (' $r$ 'selected environments) such as regions of upwelling, river mouths, spring blooms and oceanographic fronts as long as there is sufficient dissolved silicate. For nondiatom fast-growers like E. huxleyi, it seems plausible that they should do well in 
eutrophic environments where diatoms are somehow excluded from the competition, for instance where nitrate, phosphate and other nutrients are still abundant but where dissolved silicate has been exhausted. In mesocosm experiments diatoms tend to dominate the phytoplankton community except when silicate is scarce (Egge and Aksnes 1992). Such a situation occurs towards the end of spring blooms in the northeast North Atlantic (Fasham et al. 2001, Fig. 12a), and E. huxleyi blooms also occur in this area (e.g. Holligan et al. 1993a). E. huxleyi blooms do not seem to occur in those parts of High Nutrient Low Chlorophyll regions (e.g. North Pacific, high-latitude Southern Ocean) where high concentrations of dissolved silicate persist year-round.

The probable importance of silicate (lack of it) to E. huxleyi is graphically illustrated by the case of the Black Sea. Comparison of the pattern of bright waters seen in 1978-86 by the CZCS satellite (Brown and Yoder 1994) with the pattern seen by the SeaWiFS satellite since 1997 (http://orbitnet.nesdis.noaa.gov/orad2/ doc/ehux_www.html; Iglesias-Rodriguez et al. 2002) reveals that whereas CZCS detected only a few patches of bright water in the Black Sea, the whole of the Black Sea is bright in the SeaWiFS analysis. Although sediment records show that E. huxleyi has been present at some concentration in the Black Sea for about 1600 years (Hay et al. 1991), phytoplankton sampling records show a decline in diatom numbers and an increase in E. huxleyi numbers since the 1960s (Mihnea 1997; Humborg et al. 1997). What has caused the recent shift away from diatoms and towards E. huxleyi (and other flagellates)? Since 1970-72, when the Iron Gates Dam was constructed across the River Danube (which provides the majority of the freshwater inflow to the Black Sea), the river load of dissolved silicate into the Black Sea has markedly decreased while river load of nitrogen has increased. This has depressed dissolved silicate levels in the Black Sea, with wintertime concentrations decreasing from about 50 down to about $20 \mu \mathrm{Mol} \mathrm{kg}^{-1}$ (Humborg et al. 1997). The large surplus of fixed nitrogen now left over following silicate depletion by spring diatom blooms is being removed by non-diatom species.

\section{Phosphate more limiting than nitrate}

Several studies have noted anomalous N:P ratios during E. huxleyi blooms. Typically, in the ocean as a whole, the N:P ratio in surface waters is generally rather low, certainly lower than the Redfield ratio of 16:1 (Fanning 1992). In the $1991 E$. huxleyi bloom to the south of Iceland, surface layer N:P ratios were however similar to or greater than 16 in the bloom waters, and less than 16 further south (Tyrrell and Taylor 1996). In the Gulf of Maine in 1989 lowest phosphate levels were noted at bloom stations (Townsend et al. 1994) (ranging from 0.02 to 0.16 $\mu \mathrm{M}$, vs. 0.21 to $0.49 \mu \mathrm{M}$ at the non-bloom stations). Though Townsend et al. (1994) found that the phosphate concentrations were lower in bloom waters, they noted that $\mathrm{N}: \mathrm{P}$ ratios were not different (ranging from 5.9 to 6.4 at bloom and nonbloom stations), although they were lower, in both bloom and non-bloom waters, than the Redfield ratio. Van der Wal et al. (1995) found in a bloom study in 1993 in the North Sea that phosphate concentrations at bloom stations were about 0.1 
$\mu \mathrm{M}$ and about $0.3 \mu \mathrm{M}$ at non-bloom stations. $\mathrm{N}: \mathrm{P}$ ratios ranged from $6-11$ in coccolithophore-rich waters and from 13-15 in non-bloom waters. Mesocosm experiments also observed E. huxleyi success (larger final populations) for those bags manipulated by adding lots of $\mathrm{N}$ and little $\mathrm{P}$ rather than vice-versa (Egge and Heimdal 1994), and it can be seen in Fig. 3 that most E. huxleyi blooms (large black circles) occurred at lower phosphate concentrations while the same cannot be said for lower nitrate concentrations. A modeling study of the mesocosms invoked E. huxleyi success at low phosphate concentrations to explain the observations (Aksnes et al. 1994).

From a physiological perspective E. huxleyi is known to be able to synthesize the enzyme alkaline phosphatase (Kuenzler and Perras 1965; Riegman et al. 2000), which allows uptake of some fractions of dissolved organic phosphates and should therefore impart an advantage to E. huxleyi when inorganic phosphate is limiting. "Competition experiments" have been carried out by growing inoculate of several phytoplankton strains in a single chemostat, and in several such experiments greater numbers of E. huxleyi, and greater percentages out of the total, were obtained at high N/P ratios rather than at low N/P ratios (Riegman et al. 1992).

However, recent examination of nutrient data from the eastern Bering Sea during the years of the E. huxleyi blooms there suggests that those blooms occurred when $\mathrm{N}$ was limiting but $\mathrm{P}$ was abundant, suggesting that low phosphate is not an absolute requirement for the occurrence of these blooms.

\section{Low dissolved carbon dioxide}

The chemical reaction for calcification is

$$
\mathrm{Ca}^{2+}+2 \mathrm{HCO}_{3}^{-} \rightarrow \mathrm{CaCO}_{3}+\mathrm{H}_{2} \mathrm{O}+\mathrm{CO}_{2}
$$

As described by Brownlee and Taylor (this volume), the synthesis of calcium carbonate coccoliths therefore releases $\mathrm{CO}_{2}$ as a by-product, and this extra $\mathrm{CO}_{2}$ is probably available for photosynthesis. This indirect means of obtaining $\mathrm{CO}_{2}$ from $\mathrm{HCO}_{3}$ could potentially give E. huxleyi an advantage over other phytoplankton if the rate of supply of external $\mathrm{CO}_{2}$ is limiting for growth. Here this hypothesis is discussed from the ecological rather than the physiological point of view (see Rost and Riebesell this volume, for the latter). Although there is an abundance of dissolved inorganic carbon (DIC) in all ocean waters (usually more than $2000 \mu \mathrm{Mol}$ compared to a maximum of about $30 \mu \mathrm{Mol}$ of nitrate, so order 60 times more DIC than nitrate whereas phytoplankton only require about $7 \mathrm{C}$ atoms for every $\mathrm{N}$ atom), at typical $\mathrm{pHs}$ most of this carbon exists as bicarbonate $\left(\mathrm{HCO}_{3}\right.$, about $90 \%$ of total DIC) and carbonate $\left(\mathrm{CO}_{3}\right.$, about $10 \%$ of the total), with typically less than $1 \%$ as dissolved carbon dioxide $\left(\mathrm{CO}_{2}(\mathrm{aq})\right)$.

Although the pre-bloom $\mathrm{CO}_{2}(\mathrm{aq})$ concentration may be as little as $15 \mu \mathrm{Mol} \mathrm{kg}^{-1}$, when $\mathrm{CO}_{2}(\mathrm{aq})$ is depleted it is quickly (within seconds (Zeebe and Wolf-Gladrow 2001)) replenished by conversion of $\mathrm{HCO}_{3}$ to $\mathrm{CO}_{2}(\mathrm{aq})$. Because of this rapid interconversion between different dissolved carbon forms, a phytoplankton drawdown of more than $15 \mu \mathrm{Mol} \mathrm{kg}$ of carbon does not cause $\mathrm{CO}_{2}(\mathrm{aq})$ to run out. This can 
only happen if all DIC is exhausted or if the $\mathrm{pH}$ is significantly changed. In reality DIC only rarely drops below $1800 \mu \mathrm{Mol} \mathrm{kg}^{-1}$. Despite the enormous uptake by phytoplankton, it is unlikely that $\mathrm{CO}_{2}(\mathrm{aq})$ ever falls much below about $10 \mu \mathrm{Mol}$ $\mathrm{kg}^{-1}$ in the open ocean, even following intense spring blooms such as those that occur annually in the northeast North Atlantic (Tyrrell and Taylor 1995).

The preceding discussion suggests that carbon availability never sets a limit to the final amount of phytoplankton growth in a season, but it is possible that it sets a limit to the instantaneous rate of growth at the height of blooms. Despite the ever-presence of DIC, experimental evidence suggests that its rate of supply to cells can limit diatom growth rate during blooms (Riebesell et al. 2000). The hypothesis that $\mathrm{CO}_{2}$ supply by calcification is important to coccolithophores implies that they should be especially successful at the height of and towards the end of spring blooms, when growth rates are high and $\mathrm{CO}_{2}(\mathrm{aq})$ concentrations relatively low. An objective analysis does suggest that most $E$. huxleyi blooms are associated with declining nitrate concentrations (Iglesias-Rodriguez et al. 2002), which must correlate with declining $\mathrm{CO}_{2}(\mathrm{aq})$. However, blooms (or at least bright waters) persist for many months after the spring blooms in the eastern Bering Sea (Sukhanova and Flint 1998; Iida et al. 2002) and elsewhere, into Jul/Aug/Sep when shortages of nitrate and phosphate rather than of $\mathrm{CO}_{2}(\mathrm{aq})$ are most likely to be critical for growth rate. In addition to physiological/biochemical evidence against this hypothesis (Rost and Riebesell, this volume) from the ecological point of view it appears that this hypothesis is not able to explain all aspects of E. huxleyi distribution.

\section{High carbonate saturation state (carbonate ion concentration)}

A wide range of experiments, mostly on other marine calcifiers but also on $E$. huxleyi, suggest a possibly important role for carbonate ion concentration (carbonate saturation state) in determining where blooms can occur.

Coral reefs are restricted to low latitudes, most probably because of a dependence on the carbonate saturation state of seawater $(\Omega)$ (Kleypas et al. 1999a), which attains highest values between about $0-30^{\circ}$ of latitude, and then falls away towards the poles (Fig. 5). Calcium carbonate saturation state is

$$
\Omega=\left[\mathrm{Ca}^{2+}\right] \cdot\left[\mathrm{CO}_{3}^{2-}\right] / K_{s p}^{\prime}
$$

where $K_{s p}{ }_{s p}$ is the stoichiometric solubility product which takes different values for the different mineral phases aragonite (coral reefs, pteropods) and calcite (coccoliths, foraminifera shells) but for which the geographical trend is the same. Calcium concentration varies little throughout the ocean, so variability in $\Omega$ is mostly due to variability in $\mathrm{CO}_{3}{ }^{2-}$. Coral reefs today are found only where $\Omega$ is fairly high ( $\Omega_{\text {arag }}>3.0$ or so), and are generally vigorous and productive where $\Omega$ is par- 


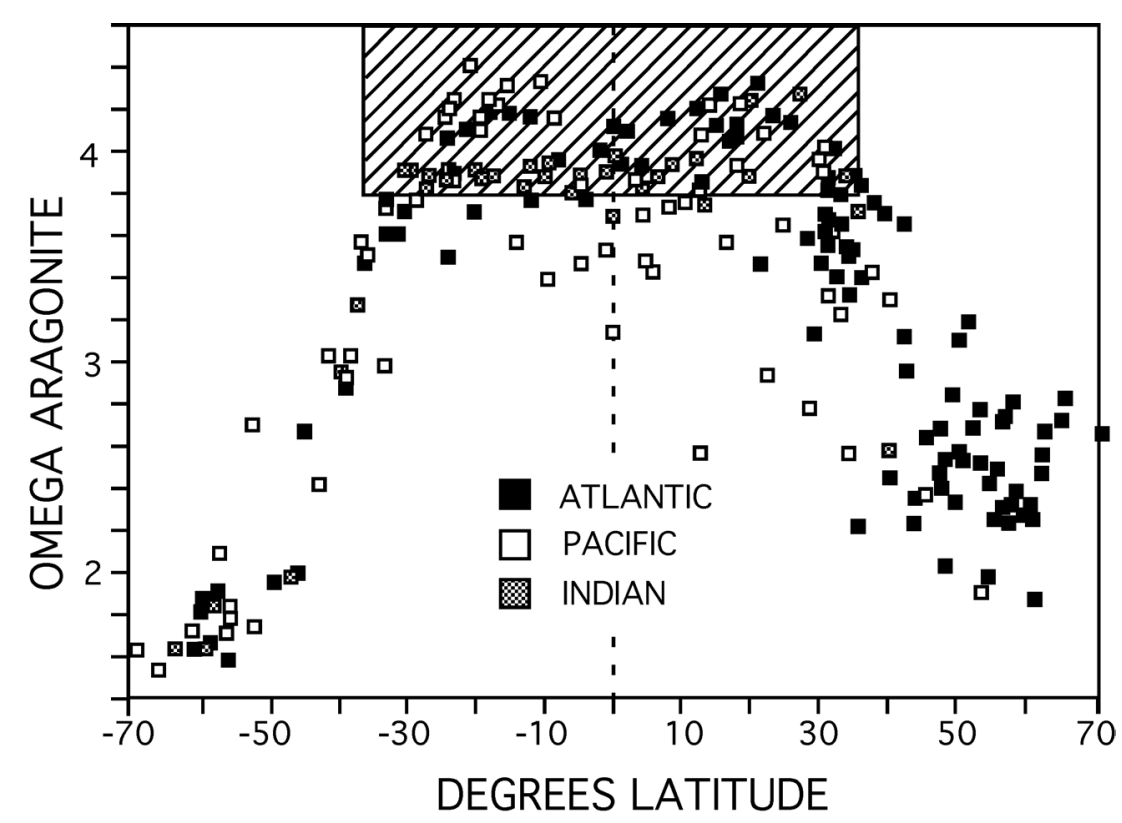

Fig. 5. Latitudinal distribution of aragonite saturation state in different oceans (taken from Opdyke and Wilkinson 1990)

ticularly high, for instance, the Bahamas, the Red Sea, and the coast of Papua New Guinea $\left(\Omega_{\text {arag }}>3.9\right.$ or so) (Kleypas et al. 1999b). Manipulation experiments on coral reefs and coralline algae have corroborated the importance of saturation state to coral reefs (references in Kleypas et al. 1999a). The coral reef biome within Biosphere II has been subjected to lowered $\Omega$, again leading to reduced calcification (Langdon et al. 2000).

Although foraminifera exhibit a global distribution including polar waters (unlike reefs which are constrained to high- $\Omega$ waters) nevertheless they too respond to the saturation state of seawater. Laboratory experiments in which foraminifera have been grown at varying carbonate ion concentrations (varying $\Omega$ ) have shown that the shell weight (thickness of the foram shells) is strongly dependent on the carbonate ion concentration (Spero et al. 1997). This was found both when $\mathrm{TCO}_{2}$ was varied while alkalinity was kept constant, and also while alkalinity was varied while $\mathrm{TCO}_{2}$ was kept constant (Spero et al. 1997). This effect, which is a precipitation effect and separate from dissolution effects related to carbonate ion concentration (Lohmann 1995), has recently been demonstrated graphically in the discovery of variation of foram shell weights over time. Barker and Elderfield (2002) recovered forams deposited well above the lysocline (so dissolution effects can be ignored) at various times back to the last glacial maximum and beyond. Forams deposited during the LGM, when carbonate ion concentration was higher because 
of the lower atmospheric $\mathrm{pCO}_{2}$, were found to be heavier than any found in the ocean today (Barker and Elderfield 2002).

This sensitivity of other marine calcifiers to carbonate ion concentration appears also to hold for coccolithophores. Coccolithophores (G. oceanica and $E$. huxleyi) in cultures, and also in field samples from the open ocean, were subjected to low $\Omega$ conditions, at which it was found that calcification rates declined and malformed coccoliths were produced (Riebesell et al. 2000; Rost and Riebesell this volume). The lowered calcification rates of Riebesell et al.'s experiments are somewhat hard to understand from a physiological point of view because $E$. huxleyi appears to obtain its carbon for coccoliths from bicarbonate $\left(\mathrm{HCO}_{3}\right)$, not from carbonate $\left(\mathrm{CO}_{3}\right)$ (Paasche 2002). If this is correct then why should $\Omega$ be important to coccolithophores? However, corals are also thought to take up bicarbonate but yet they too are found experimentally to be sensitive to carbonate ion rather than bicarbonate ion concentrations (Marubini et al. 2001).

If further work substantiates this probable link between coccolithophore calcification and saturation state, this could be of interest beyond just the calculation of carbon fluxes during E. huxleyi blooms. The distribution of coral reefs in the ocean (where they can succeed in competition with sponges, seaweeds, etc) may be heavily influenced by geographical variations in $\Omega$ (Kleypas et al. 1999b). Perhaps the geographical distribution of $\Omega$ (Fig. 5) also affects where coccolithophores in general (and E. huxleyi blooms in particular) can occur (where E. huxleyi can compete successfully with other phytoplankton), not just their calcification rate. Perhaps the absence of coccolithophores from cold polar waters is because of difficulty in building sufficiently robust coccoliths at low $\Omega$. In the same way that the geographical and temporal variation in success of diatoms is influenced by the abundance of silicate (e.g. Egge and Aksnes 1992) for diatom shell building, so too could the distribution of coccolithophores be influenced by geographical variation in the ease of coccolith building.

It is rather important to answer this question of sensitivity to carbonate ion because the emission of $\mathrm{CO}_{2}$ into the atmosphere from burning of fossil fuels is, following diffusion of large amounts of the $\mathrm{CO}_{2}$ into the surface ocean, rapidly acidifying the surface ocean and decreasing carbonate ion concentration and $\Omega$ there. It is estimated that $\Omega_{\text {arag }}$ averaged $\sim 4.6$ in the tropics 100 years ago, is currently $\sim 4.0$, and is projected to drop to $\sim 2.8$ by 2100 (Kleypas et al. 1999a). Both coccolithophores and coral reefs could become substantial casualties of the rise in atmospheric and ocean carbon. We need to understand whether coccolithophores, coral reefs, \& co. will be driven out of most or all oceanic environments by rising $\mathrm{CO}_{2}$ and consequent falling $\mathrm{CO}_{3}$.

\section{Type of grazers (microzooplankton and/or jellyfish)}

As a top-down rather than a bottom-up forcing, the respective numbers of different species of grazers at a location may influence the viability of that location for different species of phytoplankton. The major grazers of E. huxleyi in the NE At- 
lantic, as measured in 1991, were microzooplankton (Holligan et al. 1993a) and therefore variations in the density of microzooplankton could be important in determining where blooms of E. huxleyi can form.

Recently, Olson and Strom (2002) measured phytoplankton growth and microzooplankton grazing rates, by means of seawater dilution techniques inside and outside an E. huxleyi bloom area in the southeastern Bering Sea. They observed that "a reduced microzooplankton grazing is a key component in the formation and temporal persistence of Emiliania huxleyi bloom". Microzooplankton grazing seemed to shift from selective grazing on small phytoplankton cells outside the bloom to selective grazing on large cells (diatoms) inside the bloom. Reduced microzooplankton grazing of E. huxleyi than of photosynthetic dinoflagellates was also measured within a bloom off the Devon (UK) coast in July 1999 (Fileman et al. 2002), although not within a North Atlantic bloom in June 1991 where there was higher microzooplankton grazing of E. huxleyi than of the phytoplankton assemblage as a whole (Holligan et al. 1993a).

The Black Sea has seen large increases in the numbers of gelatinous carnivores (jellyfish: medusae Aurelia aurita and ctenophore Mnemiopsis leidyi) during the past two decades (Oguz et al. 2001), while during the last decade or so blooms of E. huxleyi have become a feature of the system (Cokacar et al. 2001). A similar scenario has been seen in the eastern Bering Sea, where a dramatic increase in jellyfish (dominated by the scyphozoan Chrysaora melanaster) was noted since the early 1990s (Brodeur et al. 2002). The peak of highest total biomass over the whole shelf was noted in 1997, the year of the first massive E. huxleyi blooms in the area. It is not clear whether the success of E. huxleyi is directly tied to jellyfish (via a trophic cascade). It appears from isotope ratios and stomach content analysis that Chrysaora melanaster have the same diet as juvenile pollock but that they also pray on macrozooplankton, in competition with adult pollock (Brodeur et al. 2002). Therefore, although it seems clear that jellyfish can depress zooplankton standing stocks, a direct connection of E. huxleyi appearance in 1997 with jellyfish increasing biomass remains to be proven.

In general, however, it needs to be kept in mind that it is intrinsically difficult to test hypotheses involving zooplankton or higher trophic levels due to a lack of sufficient understanding and data on their interactions with phytoplankton. Viruses specific for E. huxleyi may also play a role (Bratbak et al. 1996), but are likely to be more important in bloom termination than in bloom commencement (e.g. Wilson et al. 2002).

\section{Other possible factors}

In a review of the 'physiological ecology of marine coccolithophores', (Brand 1994), it was noted that $E$. huxleyi is likely to be $r$-selected rather than $K$-selected, since it has a high maximum growth rate (up to 2.8 doublings per day (Brand and Guillard 1981)). It was also suggested that E. huxleyi is usually found in cold waters, and in waters with low nutrient concentrations. Another review paper (Young 1994) suggested that there are three common features to the occurrence of placo- 
lith-bearing coccolithophores such as E. huxleyi: firstly, they predominate in areas of upwelling; secondly, they are usually bloom-forming; and thirdly, they are normally dominant in coastal and shallow-sea assemblages.

Neither temperature nor salinity are likely to be significant causal factors. $E$. huxleyi is known to be one of the most eurythermal and euryhaline of species (Winter et al. 1994). Even though water temperature, in combination with other parameters, appears to be a good predictor of E. huxleyi blooms (IglesiasRodriguez et al. 2002) (they are associated with water temperatures between $3^{\circ}$ and $15^{\circ} \mathrm{C}$ ), this is probably due to secondary effects of temperature, such as its effect on water stability. "In general, blooms of E. huxleyi follow those of diatoms in waters that have been recently depleted in inorganic nutrients and are becoming more stable in terms of vertical mixing (e.g. following the relaxation of upwelling, or establishment of the seasonal thermocline)" (Holligan et al. 1993b). This precludes most very cold or very warm waters. A strong salinity control on E. huxleyi blooms is ruled out by the presence of blooms in both the open ocean (average about $35 \mathrm{ppt}$ ) and the semi-saline Black Sea (average about $18 \mathrm{ppt}$ ).

Although "seeding effects" (the advection of cells from elsewhere in order to provide the starting population that is required before a bloom can take place) have been considered important in the past (Birkenes and Braarud 1952), the case study of the eastern Bering Sea suggests otherwise. In that case enormous blooms 'came from nowhere' in the space of just two years (no visible bloom in 1995 or previous years, small bloom in 1996, enormous bloom in 1997) (Merico et al. 2003). The large blooms were able to develop rapidly from what must have been a small initial population. A time sequence of satellite images http://www.soes. soton.ac.uk/staff/tt/eh/sequence.html also shows that blooms can start all along the western coast of Norway at the same time, rather than one bloom seeding another to produce a "chain reaction" of blooms.

E. huxleyi has a requirement for thiamine (vitamin $\mathrm{B}_{1}$ ) for growth, unlike many algae, but does not require vitamin $B_{12}$ (Carlucci and Bowes 1970). This may represent a further reason why $E$. huxleyi is not present during the first stages of spring blooms, but the ecological importance of vitamin $B_{1}$ has never been proven (Paasche 2002). E. huxleyi can grow well at low concentrations of iron, along with other open-ocean phytoplankton (Brand et al. 1983). However, this ability has not been shown to have any ecological significance, and E. huxleyi distribution is not at all correlated with regions of iron deficiency in the oceans.

\section{Conclusions}

Progress has been made towards uncovering the main environmental factors facilitating the development of E. huxleyi blooms. It seems unlikely that any single factor can explain all blooms. More probably a combination of conditions is required. High light and limiting silicate (to restrict diatoms) are probably essential, and high carbonate saturation state may also be critical, but much work remains to be done. 
Modern satellites are excellent tools for mapping the distribution of E. huxleyi blooms, but the possibility of mimicking conditions shows the importance of insitu verification. Annually repeating bright waters in the Barents Sea and on the Patagonian Shelf particularly need to be sampled.

\section{Acknowledgements}

We are grateful to many individuals who have helped with discussions, satellite images and data, including: Norman Kuring, Sandra Broerse, Jeremy Young, Chris Brown, Paolo Cipollini and Patrick Holligan. This work was made possible by funding from the Natural Environment Research Council (NERC) to TT (GT5/98/15/MSTB; NER/B/S/2000/00047); and from the University of Southampton via a studentship to AM. We also gratefully acknowledge financial support by the British Council to allow collaboration with Temel Oguz. The chapter has benefited from constructive comments by Patrick Holligan, Gill Malin and an anonymous reviewer.

\section{References}

Aksnes DL, Egge JK, Rosland R, Heimdal BR (1994) Representation of Emiliania huxleyi in phytoplankton simulation models: a first approach. Sarsia 79: 291-300

Archer D, Winguth A, Lea D, Mahowald N (2000) What caused the glacial/interglacial atmospheric $\mathrm{pCO}_{2}$ cycles? Rev Geophys 38: 159-189

Balch WM, Holligan PM, Ackleson SG, Voss KJ (1991) Biological and Optical-Properties of Mesoscale Coccolithophore Blooms in the Gulf of Maine. Limnol Oceanogr 36: 629-643

Balch WM, Holligan PM, Kilpatrick KA (1992) Calcification, photosynthesis and growth of the bloom-forming coccolithophore, Emiliania huxleyi. Cont Shelf Res 12: $1353-1374$

Barker S, Elderfield H (2002) Foraminiferal calcification response to glacial-interglacial changes in atmospheric $\mathrm{CO}_{2}$. Science 297: 833-836

Baudini CL, Hyrenbach KD, Koyle KO, Pinchuk A, Mendenbell V, Hunt Jr GL (2001) Mass mortality of short-tailed shearwaters in the south-eastern Bering Sea during summer 1997. Fish Oceanogr 10: 117-130

Berge G (1962) Discolouration of the sea due to Coccolithus huxleyi "bloom". Sarsia 6: $27-40$

Birkenes E, Braarud T (1952) Phytoplankton in the Oslo Fjord during a 'Coccolithus huxleyi-summer'. Avh Nor Viden Akad Oslo 1952/2: 1-23

Blackburn SI, Cresswell G (1993) A coccolithophorid bloom in Jervis Bay, Australia. Aust J Mar Fresh Res 44: 253-260

Brand LE (1994) Physiological ecology of marine coccolithophores. In: Winter A, Siesser WG (eds) Coccolithophores. Cambridge University Press, Cambridge, pp 39-49 
Brand LE, Guillard RRL (1981) The Effects of Continuous Light and Light-Intensity on the Reproduction Rates of 22 Species of Marine-Phytoplankton. J Exp Mar Biol Ecol 50: $119-132$

Brand LE, Sunda WG, Guillard RRL (1983) Limitation of marine phytoplankton reproductive rates by zinc, manganese, and iron. Limnol Oceanogr 28: 1182-1198

Bratbak G, Wilson W, Heldal M (1996) Viral control of Emiliania huxleyi blooms? J Mar Syst 9: 75-81

Brodeur RD, Sugisaky H, Hunt Jr. GL (2002) Increase in jellyfish biomass in the Bering Sea: implications for the ecosystem. Mar Ecol Prog Ser 233: 80-103

Broerse ATC, Tyrrell T, Young JR, Poulton AJ, Merico A, Balch WM, Miller PI (2003) The cause of bright waters in the Bering Sea in winter. Cont Shelf Res 23: 1579-1596

Brown CW, Yoder JA (1993) Blooms of Emiliania huxleyi (Prymnesiophyceae) in surface waters of the Nova Scotian Shelf and the Grand Bank. J Plankton Res 15: 1429-1438

Brown CW, Yoder JA (1994) Coccolithophorid Blooms in the Global Ocean. J Geophys Res-Oceans 99: 7467-7482

Burkill PH, Archer SD, Robinson C, Nightingale PD, Groom SB, Tarran GA, Zubkov MV (2002) Dimethyl sulphide biogeochemistry within a coccolithophore bloom (DISCO): an overview. Deep-Sea Res Part II-Top Stud Oceanogr 49: 2863-2885

Carlucci AF, Bowes PM (1970) Vitamin production and utilization by phytoplankton in mixed culture. J Phycol 6: 393-400

Cokacar T, Kubilay N, Oguz T (2001) Structure of Emiliania huxleyi blooms in the Black Sea surface waters as detected by SeaWIFS imagery. Geophys Res Lett 28 (24): $4607-4610$

Egge JK, Aksnes DL (1992) Silicate as Regulating Nutrient in Phytoplankton Competition. Mar Ecol-Prog Ser 83: 281-289

Egge JK, Heimdal BR (1994) Blooms of phytoplankton including Emiliania huxleyi (Haptophyta). Effects of nutrient supply in different N:P ratios. Sarsia 79: 333-348

Fanning KA (1992) Nutrient provinces in the sea: concentration ratios, reaction rate ratios, and ideal covariation. J Geophys Res 97: 5693-5712

Fasham MJR, Balino BM, Bowles MC, Anderson R, Archer D, Bathmann U, Boyd P, Buesseler K, Burkill P, Bychkov A, Carlson C, Chen CTA, Doney S, Ducklow H, Emerson S, Feely R, Feldman G, Garcon V, Hansell D, Hanson R, Harrison P, Honjo S, Jeandel C, Karl D, Le Borgne R, Liu KK, Lochte K, Louanchi F, Lowry R, Michaels A, Monfray P, Murray J, Oschlies A, Platt T, Priddle J, Quinones R, Ruiz-Pino D, Saino T, Sakshaug E, Shimmield G, Smith S, Smith W, Takahashi T, Treguer P, Wallace D, Wanninkhof R, Watson A, Willebrand J, Wong CS (2001) A new vision of ocean biogeochemistry after a decade of the Joint Global Ocean Flux Study (JGOFS). Ambio: 4-31

Fileman ES, Cummings DG, Llewellyn CA (2002) Microplankton community structure and the impact of microzooplankton grazing during an Emiliania huxleyi bloom, off the Devon coast. J Mar Biol Ass UK 82: 359-368

Findlay CS, Giraudeau J (2000) Extant calcareous nannoplankton in the Australian Sector of the Southern Ocean (austral summers 1994 and 1995) Mar Micropaleontol 40: 417-439

Furnas MJ (1990) In situ Growth-Rates of Marine-Phytoplankton - Approaches to Measurement, Community and Species Growth-Rates. J Plankton Res 12: 1117-1151 
Garcia-Soto C, Fernandez E, Pingree RD, Harbour DS (1995) Evolution and Structure of a Shelf Coccolithophore Bloom in the Western English-Channel. J Plankton Res 17: 2011-2036

Hardy A (1956) The Open Sea, Pt. I. The World of Plankton. Collins, London

Hay BJ, Arthur MA, Dean WE, Neff ED, Honjo S (1991) Sediment deposition in the Late Holocene abyssal Black Sea with climatic and chronological implications. Deep-Sea Res 38 (Suppl. 2): S1211-S1235

Head RN, Crawford DW, Egge JK, Harris RP, Kristiansen S, Lesley DJ, Maranon E, Pond D, Purdie DA (1998) The hydrography and biology of a bloom of the coccolithophorid Emiliania huxleyi in the northern North Sea. J Sea Res 39: 255-266

Holligan PM, Robertson JE (1996) Significance of ocean carbonate budgets for the global carbon cycle. Glob Change Biol 2: 85-95

Holligan PM, Viollier M, Harbour DS, Camus P, Champagnephilippe M (1983) Satellite and Ship Studies of Coccolithophore Production Along a Continental-Shelf Edge. Nature 304: 339-342

Holligan PM, Fernandez E, Aiken J, Balch WM, Burkill PH, Finch M, Groom SB, Malin G, Muller K, Purdie DA, Robinson C, Trees CC, Turner SM, Van der Wal P (1993a) A biogeochemical study of the coccolithophore Emiliania huxleyi in the north Atlantic. Global Biogeochem Cy 7: 879-900

Holligan PM, Groom SB, Harbour DS (1993b) What controls the distribution of the coccolithophore, Emiliania huxleyi, in the North Sea? Fish Oceanogr 2: 175-183

Humborg C, Ittekot V, Cociasu A, Bodungen BV (1997) Effect of Danube River dam on Black Sea biogeochemistry and ecosystem structure. Nature 386: 385-388

Hunt Jr. GL, Stabeno PJ (2002) Climate change and the control of energy flow in the south eastern Bering Sea. Prog Oceanogr 55: 5-22

Iglesias-Rodriguez MD, Brown CW, Doney SC, Kleypas JA, Kolber D, Kolber Z, Hayes PK, Falkowski PG (2002) Representing key phytoplankton functional groups in ocean carbon cycle models: Coccolithophorids. Global Biogeochem Cy 16: doi.10.1029/ 2001 GB001454

Iida T, Saitoh SI, Miyamura T, Toratami M, Fukushima H, Shiga N (2002) Temporal and spatial variability of the coccolithophore blooms in the eastern Bering Sea, 1998-2001. Prog Oceanogr 55: 165-175

Kleypas JA, Buddemeier RW, Archer D, Gattuso JP, Langdon C, Opdyke BN (1999a) Geochemical consequences of increased atmospheric carbon dioxide on coral reefs. Science 284: 118-120

Kleypas JA, McManus JW, Menez LAB (1999b) Environmental limits to coral reef development: where do we draw the line? Am Zool 39: 146-159

Kristiansen S, Thingstad TF, Van der Wal P, Farbrot T, Skjoldal EF (1994) An EmilianiaHuxleyi Dominated Subsurface Bloom in Samnangerfjorden, Western Norway - Importance of Hydrography and Nutrients. Sarsia 79: 357-368

Kuenzler EJ, Perras JP (1965) Phosphatases of marine algae. Biol Bull 128: 271-284

Lampert L, Queguiner B, Labasque T, Pichon A, Lebreton N (2002) Spatial variability of phytoplankton composition and biomass on the eastern continental shelf of the Bay of Biscay (north-east Atlantic Ocean). Evidence for a bloom of Emiliania huxleyi (Prymnesiophyceae) in spring 1998. Cont Shelf Res 22: 1225-1247

Langdon C, Takahashi T, Sweeney C, Chipman D, Goddard J, Marubini F, Aceves H, Barnett H, Atkinson MJ (2000) Effect of calcium carbonate saturation state on the calcification rate of an experimental coral reef. Global Biogeochem Cy 14: 639-654 
Lohmann GP (1995) A Model for variation in the chemistry of planktonic foraminifera due to secondary calcification and selective dissolution. Paleoceanography 10: 445-457

Malin G, Turner S, Liss P, Holligan P, Harbour D (1993) Dimethylsulfide and Dimethylsulphoniopropionate in the Northeast Atlantic During the Summer Coccolithophore Bloom. Deep-Sea Res Part I-Oceanogr Res Pap 40: 1487-1508

Mankovsky VI, Vladimirov VL, Afonin EI, Mishonov AV, Solovev MV, Anninskiy BE, Georgieva LV, Yunev OA (1996) Long-term variability of the Black Sea water transparency and factors determining its strong decrease in the late 1980s, early 1990s: Sevastopol, Ukraine, Marine Hydrophysical Institute: 32

Marubini F, Barnett H, Langdon C, Atkinson MJ (2001) Dependence of calcification on light and carbonate ion concentration for the hermatypic coral Porites compressa. Mar Ecol-Prog Ser 220: 153-162

Merico A, Tyrrell T, Brown CW, Groom SB, Miller PI (2003) Analysis of satellite imagery for Emiliania huxleyi blooms in the Bering Sea before 1997. Geophys Res Lett 30: 1337 doi:10.1029/2002GL016648

Mihnea PE (1997) Major shifts in the phytoplankton community (1980-1994) in the Romanian Black Sea. Oceanol Acta 20: 119-129

Murata A, Takizawa T (2002) Impact of a coccolithophorid bloom on the $\mathrm{CO}_{2}$ system in surface waters of the Bering Sea shelf. Geophys Res Lett 29

Nanninga HJ, Tyrrell T (1996) Importance of light for the formation of algal blooms by Emiliania huxleyi. Mar Ecol-Prog Ser 136: 195-203

Olson MB, Strom SL (2002) Phytoplankton growth, microzooplankton herbivory and community structure in the southeast Bering Sea: insight into a formation and persistence of an Emiliania huxleyi bloom. Deep-Sea Res II 49: 5969-5990

Opdyke BN, Wilkinson BH (1990) Paleolatitude distribution of Phanerozoic marine ooids and cements. Palaeogeog Palaeocl 78: 135-148

Oguz T, Malanotte-Rizzoli P, Ducklow HW (2001) Simulations of phytoplankton seasonal cycle with multi-level and multi-layer physical-eco system models: the Black Sea example. Ecol Model 144: 295-314

Paasche E (2002) A review of the coccolithophorid Emiliania huxleyi (Prymnesiophyceae), with particular reference to growth, coccolith formation, and calcificationphotosynthesis interactions. Phycologia 40: 503-529

Paasche E, Klaveness D (1970) A physiological comparison of coccolith-forming and naked cells of Coccolithus huxleyi. Arch Mikrobiol 73: 143-152

Riebesell U, Zondervan I, Rost B, Tortell PD, Zeebe RE, Morel FMM (2000) Reduced calcification of marine plankton in response to increased atmospheric $\mathrm{CO}_{2}$. Nature 407: 364-367

Riegman R, Noordeloos AAM, Cadée GC (1992) Phaeocystis blooms and eutrophication of the continental coastal zones of the North Sea. Mar Biol 112: 479-484

Riegman R, Stolte W, Noordeloos AAM, Slezak D (2000) Nutrient uptake and alkaline phosphatase (EC 3:1:3:1) activity of Emiliania huxleyi (Prymnesiophyceae) during growth under $\mathrm{N}$ and $\mathrm{P}$ limitation in continuous cultures. J Phycol 36: 87-96

Robertson JE, Robinson C, Turner DR, Holligan PM, Watson AJ, Boyd P, Fernandez E, Finch M (1994) The Impact of a Coccolithophore Bloom on Oceanic Carbon Uptake in the Northeast Atlantic During Summer 1991. Deep-Sea Res Part I-Oceanogr Res Pap 41: 297-314

Spero HJ, Bijma J, Lea DW, Bemis BE (1997) Effect of seawater carbonate concentration on foraminiferal carbon and oxygen isotopes. Nature 390: 497-500 
Stabeno PJ, Bond NA, Kachel NB, Salo SA, Schumacher JD (2001) On the temporal variability of the physical environment over the south eastern Bering Sea. Fish Oceanogr 10: $81-98$

Stolte W, Kraay GW, Noordeloos AAM, Riegman R (2000) Genetic and physiological variation in pigment composition of Emiliania huxleyi (Prymnesiophyceae) and the potential use of its pigment ratios as a quantitative physiological marker. J Phycol 36: 529-539

Sukhanova IN, Flint MV (1998) Anomalous blooming of coccolithophorids over the eastern Bering Sea shelf. Oceanology 38: 502-505

Sverdrup HU (1953) On conditions for the vernal blooming of phytoplankton. Journal Conseil International pour l'Exploration de la Mer 18: 287-295

Townsend DW, Keller MD, Holligan PM, Ackleson SG, Balch WM (1994) Blooms of the coccolithophore Emiliania huxleyi with respect to hydrography in the Gulf of Maine. Cont Shelf Res 14: 979-1000

Tyrrell T, Taylor AH (1995) Latitudinal and Seasonal-Variations in Carbon-Dioxide and Oxygen in the Northeast Atlantic and the Effects on Emiliania Huxleyi and Other Phytoplankton. Global Biogeochem Cy 9: 585-604

Tyrrell T, Taylor AH (1996) A modelling study of Emiliania huxleyi in the NE Atlantic. J Mar Syst 9: 83-112

Tyrrell T, Holligan PM, Mobley CD (1999) Optical impacts of oceanic coccolithophore blooms. J Geophys Res-Oceans 104: 3223-3241

Van der Wal P, Kempers RS, Veldhuis MJW (1995) Production and downward flux of organic matter and calcite in a North Sea bloom of the coccolithophore Emiliania huxleyi. Mar Ecol-Prog Ser 126: 247-265

Weeks SJ, Currie B, Bakun A (2002) Satellite imaging - Massive emissions of toxic gas in the Atlantic. Nature 415: 493-494

Westbroek P, Brown CW, Van Bleijswijk JDL, Brownlee C, Brummer GJ, Conte M, Egge JK, Fernandez E, Jordan RW, Knappertsbusch M, Stefels J, Veldhuis MJW, Van der Wal P, Young J (1993) A model system approach to biological climate forcing: the example of Emiliania huxleyi. Global Planet Change 8: 27-46

Wilson WH, Tarran GA, Schroeder D, Cox M, Oke J, Malin G (2002) Isolation of viruses responsible for the demise of an Emiliania huxleyi bloom in the English Channel. J Mar Biol Assoc UK 82: 369-377

Winter A, Jordan RW, Roth PH (1994) Biogeography of living coccolithophores in ocean waters. In: Winter A, Siesser WG (eds) Coccolithophores. Cambridge University Press, Cambridge, pp 161-177

Winter A, Elbrächter M, Krause G (1999) Subtropical coccolithophores in the Weddell Sea. Deep-Sea Res I 46: 439-449

Young JR (1994) Functions of coccoliths. In: Winter A, Siesser WG (eds) Coccolithophores. Cambridge University Press, Cambridge, pp 63-82

Zeebe RE, Wolf-Gladrow D (2001) $\mathrm{CO}_{2}$ in Seawater: Equilibrium, Kinetics, Isotopes. Elsevier, Amsterdam 